\title{
Recent developments in the European law of public contracts
}

Andrea Mozzati and Giorgio Afferni*

\section{Lines of development}

With the adoption of Directive 2004/17 and Directive 2004/18 the European Institutions made a significant step towards the rationalization and simplification of the law concerning public cohtracts and public procurements. ${ }^{1} \mathrm{How}-$ ever, it is clear today that these objectives were not fully obtained. Indeed, both the Commission and the European Parliament have recently stressed the opportunity of a new intervention in these areas for a further simplification and modernization of the law. ${ }^{2}$

Very significant in this respect is the Green Paper adopted by the Commission on 27 January 2011. ${ }^{3}$ The goal of this document is to update the law of public procurement in order to make the award procedures more flexible and to enable their use for the promotion of a wider set of European policies.

A superficial explanation of this 'law making activism' may be that the provisions of Directives 2004/17 and Directive 2004/18 are not sufficiently well drafted. In reality, it seems that the interventionism of European Institutions has much deeper roots than mere instances of legislative technical problems.

In the first place, there is an emerging trend to use the European law of public contracts for the promotion of values protected by the Treaty other than the value of competition, which is still central. For example, the objective of

* Andrea Mozzati, Lecturer in European Administrative Law in the University of Genoa, is the author of $\$$ II.1-4. Giorgio Afferni, LL.M. (Harvard '02). Ph.D. (Pisa '06), Lecturer in European Private Law in the University of Genoa, is the author of $\mathbb{\$}$ II. 5-7. $\mathbb{I}$ is common.

1 See also the previous reports by P. Alberti, 'The evolution of Public Contracts in European Law' (2006) European Review of Contract Law 391 and G. Taccogna, 'The evolution of European Community law on public procurement between 2006 and 2008' (2009) European Review of Contract Law 193.

2 For the Commission see the Green paper on the modernisation of EU public procurement policy: towards a more efficient European Procurement Market 27. 1. 2011 COM(2011). For the European Parliament see the Resolution 8 May 2010 on new developments in public procurement [2009/2175 (INI)].

3 Cf Green paper, $n 2$ above. 
'greater efficiency of public spending' is getting more important every day. ${ }^{4}$ European Institutions are also stressing new objectives, such as the protection of the environment and of workers performing public contracts.

These developments will determine a shift in the paradigm of the European law of public contracts. The Conmmission, ftself recognized in the Green Paper that there might be significant contrasts between these new social interests and the paramount value of competition. For example, the goal of efficiency of public spending is not always in line with the goal of ensuring competition. This could be the case in those areas where only few subjects are in the position to perform the public contract as expected by the contracting authority. In such areas, efficiency of public spending might require that only these subjects be invited to take part in a negotiation procedure without a general notice to the public. This procedure would make significant savings in time, resources, and administrative costs. However, contracting authorities would be required by ordinary rules to make use also in these cases of public procedures, either open or restricted. More examples could be made with respect to environment protection. This would be the case where the invitation to participate in the awarding procedure would require the winner to perform the contract making could present an obstacle to competition by creating barriers to the participation to the award procedure.

The general impression is that the European law of public contracts is increasingly assuming new dimensions as a consequence of the extension of the competences of the EU that was recently established by the Treaty of Lisbon. This seems to be the real reason for the recent activism of European Institutions and for the early obsolesence of Directive 2004/17 and Directive 2004/
18.

A further proof of the enlargement of the areas of intervention of the EU in the field of public contracts can be found in the fact that European Institutions clearly show the tendency to govern not only award procedures, but also performance of public contracts (modifications, subcontracting, etc). Moreover, we should not overlook the contribution of EU law to remedies and judicial procedure (Directive 1989/665 and Directive 1992/13). This evolution finally led to the adoption of Directive 2007/66 that provides an almost complete set of remedies and procedural rules that are binding on Member States. The natural consequence of the fact that the EU law of public contracts is acquiring a more comprehensive scope is the decline of the so-called 'procedural autonomy', ie the role traditionally reserved to national laws within the area of competence of the EU to set forth with a certain degree of autonomy 
the rules of administrative and judicial procedures. In this respect, it is noteworthy that in several parts of the Green Paper on the modernisation of EU public procurement policy the Commission complains about 'national overruling' (so-called gold-plating). In other words, the Commission seems to consider many interventions of national legislators as factors that unnecessarily complicate the legal framework.

Under such circumstances, the Commission and the European Court of Justice (ECJ) have already become the central act@rs of the system. The Commission carries on a 'qualified interpretation' of EU law, which is binding upon Member States and which might lead to the opening of an infraction procedure. In this respect, it is noteworthy that the Commission - with the goal of broadening its instruments of intervention - is inclined to consider an illegal award of a public contract as a State aid infringing against EU competition law. On the other hand, the ECJ has been increasingly called upon to provide a delicate interpretation of directives, as demonstrated by the increasing number of ECJ decisions in the last three years.

This evolution has had significant methodological consequences for the legal practitioner. Today, absolute priority must be given to the analysis and interpretation of European law in its several components, leaving only residual space to national law. This is even true for some areas of public contract law not directly covered by Directive 2004/17 and Directive 2004/18. In the following pages we will briefly discuss, along these lines of development, the most significant case law of the ECJ on public contracts in the years 20092011.

\section{The case law of the ECJ}

\section{The notion of contracting authority}

Directive 2004/18 applies to public contracts awarded by the State, by regional or local authorities and by other bodies governed by public law. While the definitions of State and of regional or local authorities are relatively simple, the definition of body governed by public law is more complex, considering that this notion has a residual nature and that therefore it is meant to be general in scope. However, national and European case law is providing some clear criteria for its definition.

Beginning with its decision in the case Mannesmann of $1998,{ }^{5}$ the ECJ adopted a substantive, rather than formal, approach. For example, it disregarded the

5 Case 44/96 Mannesmann Anlagenbau Austria AG v Strobal Rotationsdruck GmbH [1998] ECR I-73 (ECJ). 
fact that the subject governed by the public hand was a company or the fact that its activity was governed by private law. Beginning with the case Korho$n e n,{ }^{6}$ the circumstances taken into account in order to affirm the public nature of the subject are, on the one side, the level of real competition, and, on the other side, its financial and economic governance.

As the Green Paper clearly stated, proper application of these elements requires a detailed case-by-case analysis, taking into account the degree of competition in the marketplace and the question of "whether the body is acting for profit and bears the losses and risks associated with its activity. ${ }^{7}$ Therefore, a subject that, while engaging in an economic activity making use of private law, benefits from a regime that prevents its bankruptcy or foresees that the public hand will take over any loss, should be qualified as a body governed by public law.

In this respect, the ECJ held a noteworthy decision in the case AOK Rheinland/Hamburg, ${ }^{8}$ concerning the position of heath social insurance bodies, which in German law are considered bodies of public law with legal personality and are financed mostly through mandatory contributions from its members. ${ }^{9}$ The ECJ had to establish whether such a financial mechanism is equivalent to public financing. Consistently with its prior decision in the case Bayerischer Rundfunk, ${ }^{10}$ the ECJ stated that the requirement of public financing is satisfied not only by the direct financing from the State or other public body, but also from indirect financing. ${ }^{11}$ On the base of this argument, the ECJ classified statutory health insurance schemes as bodies governed by public law. The Court considered that the mechanism of financing is governed by acts of the State, is enforced by public authorities, and is ensured by a system of collection of contributions that is governed by rules of public law. ${ }^{12}$

Noteworthy also is the sector of public utilities. At the outset, two circumstances should be mentioned. On the one side, public firms are still the majority. On the other side, some of these industries have been liberalized (electricity and gas; exploration and extraction for hydrocarbons; postal services; etc). The combination of these two circumstances implies that many subjects

6 Case 18/01 Arkkitebtuuritoimisto Riitta Korbonen Oy, Arkkitehtuuritoimisto Pentti Toivanen $\mathrm{Oy}$ e Rakennuttajatoimisto Vilho Tervomaa v Varkauden Taitotalo Oy [2003] ECR I-5321 (ECJ).

7 Green paper, $n 3$ above, par 1.3.

8 Case 300/07 Hans \& Christophorus Oymanns GbR, Orthopadie Schubtechnik v AOK Rheinland/Hamburg [2009] ECR I-4779 (ECJ).

9 Cf par $12 \mathrm{ff}$ (par 15 in particular).

10 Case 337/06 Bayerischer Rundfunk and others v Gewa and Warnecke [2007] ECR I-11173 (ECJ). On this decision of Taccogna, n 1 above, 195.

11 Case 300/07, n 8 above, par 51.

12 Ibid par 57. 
operating in these industries are excluded from the application of Directive 2004/17.

Moreover, Article 30 of Directive 2004/17 enables the Commission to exclude the application of the Directive if the level of competition to which the operators are exposed is such to ensure the requested level of transparency and respect for the principle of equality of treatment in the award of contracts. Up to now the Commission has adopted sixteen decisions excluding the application of Directive 2004/17 to contracts of public or prifate subjects operating in industries that have been liberalized (production and sale of electricity, sale of gas, oil and natural gas sector, parts of postal services, such as logistic, packages, and financial services, etc).

2 Cooperation between public authorities in the performance of the contract and the IPPP

From the point of view of economic operators and legal practitioners, one of the most important issues consists in the definition of the limits of public intervention in the production of goods and services.

In this respect, two opposed and potentially contrasting values should be considered. On the one side, the 'constitutional' duty of European Institutions not to undermine the sphere of autonomy in political and administrative decision making by national public authorities, particularly local authorities, also in consideration of the principle of subsidiarity. On the other side, there is the necessity to protect competition, which implies not only a preference for public award procedures, but also the necessity not to enlarge excessively the scope of operation of public bodies at the expenses of private firms, which might need to compete with public bodies that enjoy the benefit of monopolies and other privileges. ${ }^{13}$

After the approach taken by the ECJ in the case Bressanone Parcheggi, ${ }^{14}$ which has been criticised as excessively restrictive, it seems that the European Institutions now favour a more mature and articulated approach to these issues. As recognized by the Commission, ${ }^{15}$ directives on public contracts should not be used for regulating instances of cooperation between public bodies for the execution of works or the supply of goods or services.

Therefore, a distinction should be drawn between, on the one side, agreements made between public bodies for the fulfilment of their public duties within their own right of self-organization and, on the other side, public contracts that must be open to competition. Along this line, it is possible to distinguish,

13 Cf Alberti, n 1 above, 394.

14 Case 458/03 Bressanone Parcheggi v Comune di Bressanone [2005] ECR I-8585 (ECJ).

15 Cf Green paper, n 3 above, par 2.3. 
on the base of the recent case law of the ECJ, between two different kinds of public-public cooperation.

In the first place, 'internal cooperation' (so-called in-house provision) should be mentioned. This kind of cooperation refers to the award of public contracts to a public body that is subject/to a control from the contracting authority similar to the control that the latter have over its own departments and that carries out the greatest part of its activities with the same authority.

In this respect, the ECJ, in its most recent decisions, ${ }^{16}$ has relaxed the previous rigidity of its view, adopting a more flexible definition of the requirement of 'similar control'. Very significant is the recent decision in the case Sea, ${ }^{17}$ where a local authority had acquired a minority participation in a company with wholly public capital, simultaneously awarding to the same company the service of collecting, transporting and disposing of solid urban waste.

Firstly, the Court held that the mere fact that the capital of the company is open to private investors (as foreseen by the statute of the company) must not represent by itself an obstacle to the qualification of the matter as 'in house': to admit this possibility would keep in indefinite suspense the determination whether or not the capital of a company awarded a public procurement contract is public and therefore would not be consistent with the principle of legal certainty. ${ }^{18}$ With this decision, one of the circumstances that prevents a qualification as in-house provision foreseen by the decision Parcheggi Bressanone has been abandoned.

Secondly, following its previous decision in the case Coditel Brabant, ${ }^{19}$ the ECJ confirmed that a 'similar control' must not be exercised individually by the public authority, but might also be exercised jointly by the public authorities which are members of that company. Therefore, in house provision might exist also in the case where the public authority acquires a minority share in a certain company. ${ }^{20}$

Thirdly, the fact that the contracting company has some kind of contractual relations also with third parties (other than the public authorities that are its shareholders) cannot be considered as an obstacle to the qualification of the relation as in-house, provided that these activities with third parties remain ancillary and marginal. ${ }^{21}$

16 Cf Taccogna, n 1 above, 196.

17 Case 573/07 Sea srlv Comune di Ponte Nossa [2009] ECR I-8127 (ECJ).
18 Ibid par 49.

19 Case 324/07 Coditel Brabant SAv Commune d'Uccle and Région de Bruxelles-Capitale [2008] ECR I-8457 (ECJ).

20 Ibid par $63 \mathrm{ff}$.

21 Ibid par 78-80. 
Finally, the ECJ held that, in the case of a plurality of shareholder authorities, the establishment of committees made up of representatives of these shareholder authorities finalized to enable a tighter control on the administration of the company contributes to the satisfaction of the requirement of 'similar control'. ${ }^{22}$

Apart from in-house provision, which represents a kind of vertical relation, the ECJ dealt with cases of 'horizontal coóperation' between public authorities. Such cases are also excluded from the application of the directives on public procurement.

In its decision in the case Stadtreinigung Hamburg, ${ }^{23}$ the ECJ held that inhouse provision - ie the use of internal bodies jointly controlled - is not the only kind of public-public cooperation. Two or more independent public authorities may establish a contractual relation through the means of noninstitutionalised horizontal cooperation. This particular case dealt with a contract stipulated by four German local authorities with Stadtreinigung Hamburg for the disposal of urban waste in return for payment.

Moreover, the ECJ, within its continuous work of construction and systematisation of EU law on public contracts, codified the rules on Institutionalised Public-Private Partnerships (IPPP), substantially adopting (as is usually the case in the constant dialogue between the two European Institutions) the views taken by the Commission in its Communication on the application of Community law on public procurement and concessions to institutionalised PPP. ${ }^{24}$

In this respect, in the case Acoset, ${ }^{25}$ the Court denied that a double procedure is necessary for the creation of a semi-public company and for the award to the same company of certain services. Therefore, one single procedure is sufficient both for the selection of the private partner and for the award of the contract to the new company. It might be noticed that the requirement of a double procedure would be against the principle of efficiency of the procedures and the more general value of efficiency of public spending, which - as pointed out in the introductory paragraph - represents today a central concern for European Institutions.

On the other hand, in its decision in the case Mebilainen $O y,{ }^{26}$ the ECJ held that it is against EU law for a public authority to conclude a contract without a public procedure with a private company for the purpose of establishing a

22 Ibid par 81-86.

23 Case 480/06 Commission of the European Communities v Federal Republic of Germany [2009] ECR I-4747 (ECJ).

24 UJ 2008, C91, 4.

25 Case 196/08 Acoset v Conferenza Sindaci e Presidenza Prov Reg ATO Idrico Ragusa [2009] ECR I-9913 (ECJ).

26 Case 215/09 Mehilainen Oy, Terveystalo Healthcare Oy v Oulun kaupunki 22. 12.2010 (ECJ). 
joint venture in the form of a company owned through shares that provides occupational health care and welfare services for the benefit of the staff of both partners. This decision of the Court is based on the argument that the award of such services by a community to a private - public partnership is an autonomous act. Therefore, Directive 2,004/18 applies.

\section{The notion of public contract and its distinction from the notion of concession}

As insistently showed by case law, it is not always easy to determine what is intended by the notion of a public contract as defined by Directive 2004/17 and Directive 2004/18, not only for the application of the provisions of these directives, but also for the application of the procedural provisions foreseen by Directive 89/665 and Directive 92/13, as amended by Directive 2007/66.

In its decision in the case Helmut Müller $\mathrm{FmbH}^{27}$ the ECJ was called upon to clarify the criteria for the classification of a contract of sale between a public authority (the seller) and a private firm (the buyer). The contract was conditioned to the circumstance that the buyer was to perform a project of urban development, which should have been approved by the local municipality.

The ECJ held that generally the contract of sale of an immovable good does not qualify as a public contract of works under Directive 2004/18. On the other hand, this directive applies when the public authority assumes the position of purchaser and not of seller, to the extent that the objective of such a contract is the execution of works. ${ }^{28}$ Moreover, it does not matter that there is a public interest of a third public authority (in this case, the local municipality) to the performance of the works in accordance with a project or urban development. The ECJ held that the concept of 'public works contracts' within the meaning of Directive 2004/17 and of Directive 2004/18 requires that the works, which are the subject of the contract, be carried out for the contracting authority's immediate economic benefit. While it is not necessary that the service takes the form of the acquisition of a material or physical object, it might not be extended to the point of including the achievement of an objective in the public interest, such as the development or coherent planning of part of an urban district. ${ }^{29}$

In the following case Club Hotel Loutraki, ${ }^{30}$ the ECJ held that a mixed contract of which the main object is the acquisition by an undertaking of $49 \%$ of 27 Case 451/08 Helmut Müller GmbH v Bundesanstalt für Immobilienaufgaben 25. 3. 2010
(ECJ).

28 Ibid par 41.

29 Ibid par 54-55.

30 Joined cases 145/08 and 149/08 Club Hotel Loutraki AE, Athinaiki Techniki AE, Evangelos Marinaki v Ethniko Symvoulio Radiotileorasis, Ypourgos Epikrateias 6.5.2010 (ECJ). 
the capital of a public undertaking and the ancillary object, indivisibly linked with that main object, is the supply of services (consisting in taking over management of the casino business, in return for payment) and the performance of works (consisting in the implementation of a development plan) does not, as a whole, fall within the definition of public contract.

The ECJ reached this conclusion on the basis ó the fact that the main object of the contract is the acquisition of the shares of the company, while the supply of services and the performance of works play an artillary role. As a consequence, while this contract must observe the basic rules and general principles of the Treaty, in particular those on freedom of establishment and the free movement of capital, it is not subject to the provisions of the Directive on remedies that apply only to contracts for public works, supply and services and to public concessions.

Another area of intense debate in the case law is the distinction between public contracts and concessions, which are subject to different regulations as far as award procedures are concerned.

It is well settled in the case law of the ECJ that the distinction between public contracts and concessions is based on the kind of consideration received by the economic operator for his work or service. In the case of public contracts, the consideration is paid directly by the contracting authority to the economic operator. In case of a concession, the consideration to be paid to the economic operator consists in the right to exploit the work or service, with the consequence that the operating risk faced by the contracting authority is shifted on the economic operator. ${ }^{31}$ However, it is not entirely clear how the notion of risk that is relevant to this distinction should be defined.

Recently, two decisions of the ECJ contributed significantly to solving some of the residual uncertainties on how the relevant risk for the classification of a contract as public contract or concession should be defined.

In the first case (WAZV Gotha), ${ }^{32}$ the ECJ was asked to clarify the criteria for the classification of a contract concerning the services of water distribution and disposal of sewage. The provisions of the contract were such as to classify it as a typical service concession (considering the fact that the economic operator was receiving its consideration from the users of the services). However, the issue was complicated by the fact that in the sector of water distribution and disposal of sewage the risk that is shifted on to the economic operator is significantly reduced by the presence of stringent public regulation.

31 Cf case 196/08, n 25 above, par 39, 41 and case 573/07, n 17 above, par 32-34.

32 Case 206/08 Wasser- und Abwasserzweckverband Gotha und Landkreisgemeinden (WAZV Gotha) v Eurawasser Aufbereitungs- und Entsorgungsgesellschaft mbH [2009] ECR I-8377 (ECJ). 
The ECJ clarified that it is sufficient for a contract to be classified as a concession where the supplier assumes all, or at least a significant share, of the operating risk faced by the contracting authority, even if that risk is, from the outset, very limited on account of the detailed rules of public law governing that service.

Also very significant is the second decision of the ECJ, in the case Stadler. ${ }^{33}$ This case dealt with the award from a group of communities to a private operator of a contract for the provision of rescue services. The consideration for the service was to be provided by a third party (a social security institution). The ECJ held that a contract may be classified as a service concession when the economic operator runs an operating risk, albeit a very limited one, by reason inter alia of the fact that the amount of the usage fees in question depends on the result of annual negotiations with third parties, and where it is not assured full coverage of thé costs incurred in managing its activities.

\section{Procedural means for the award of public contracts}

As far as the means of the procedures for the award of public contracts is concerned, it has already been mentioned in the introduction that EU law is acquiring an increasingly comprehensive scope, which restricts national laws to a residual and marginal scope.

In this respect the decision of the ECJ in the case Commission v French is very significant. ${ }^{34}$ In this case the ECJ dealt with the compatibility with EU law of a process introduced by the French legislator (the so-called marchés de definition), outside the ordinary procedures foreseen by Directive 2004/17 and Directive 2004/18 (open, restricted and negotiated procedures; competitive dialogue). The ECJ admitted that Directive 2004/18 does not seek to establish complete harmonisation of the rules governing public procurement in the Member States. However, it added that the procedures for the award of public contracts that the Member States are permitted to use are listed exhaustively in Article 28 of that directive. ${ }^{35}$

With respect to the same principle of procedural autonomy, the ECJ had to deal also with the issue of whether Member States are free to introduce grounds for exemptions from public competition beyond those already provided by the relevant directives. On this issue, the ECJ seems to have taken a more flexible approach than the approach showed with respect to the possibility of the adoption of new procedures. Generally, the ECJ has affirmed that the list of

33 Case 274/09 Privater Rettungsdienst und Krankentransport Stadler v Zweckverband für Rettungsdienst und Fenerwehralarmierung Passau 10.3.2011 (ECJ).

34 Case 299/08 European Commission v French Republic [2009] ECR I-11587 (ECJ).

35 Ibid par 28. 
grounds of exclusion permitted by the directives is closed. However, it did not prevent the possibility for Member States to introduce rules aimed at, in particular, guaranteeing respect for the principles of equality of treatment and transparency. However, the additional Grounds of exclusion introduced at a national level must not go beyond what is necessary to achieve those objectives. For example, in its decision in the case Assitur, ${ }^{36}$ the ECJ held as contrary to the principle of proportionality the provision of Italian law that foresees an absolute prohibition on simultaneous and competifing participation in the same tendering procedure by undertakings linked by a relationship of control or affiliated to one another, without permitting them an opportunity to demonstrate that that relationship did not influence their conduct in the course of that tendering procedure.

For similar reasons, in its decisipn in the case Serrantoni, ${ }^{37}$ the ECJ held as contrary to EU law the provision of Italian law that prescribes that both a permanent consortium and its member companies are automatically excluded from participating in a procedure where those companies have submitted tenders in competition with the consortium's tender in the context of the same procedure, even if the consortium's tender was not submitted on behalf of and in the interests of those companies.

With respect to award criteria, the ECJ has restated its traditional and consolidated view that the contracting authority must keep qualitative selection criteria separate from award criteria (Commission v Hellenic Republic). ${ }^{38}$ In this case, the ECJ found that it would be contrary to this rule to permit the adoption in the contract notice of a qualitative selection criterion, such as the previous experience of the economic operator, as if it was an award criterion. Finally, in the case $E C \mathrm{v}$ Ireland, ${ }^{39}$ the ECJ held that the contracting authority is not permitted to alter the weighting of the award criteria for a public contract following an initial review by the award commission of the tenders submitted.

\section{Liability for damages of contracting authorities}

The ECJ also had the opportunity to take its case law a step further with respect to the issue of the civil liability of contracting authorities. Article 2(1)

36 Case 538/07 Assitur srl v Camera di Commercio Industria Artigianato e Agricoltura di Milano [2009] ECR I-4219 (ECJ).

37 Case 376/08 Serrantoni srl, Consorzio stabile edili scrl v Comune di Milano [2009] ECR I-12169 (ECJ).

38 Case 199/07 Commission of the European Communities v Hellenic Republic [2009] ECR I-10669 (ECJ).

39 Case 226/09 Commission of the European Communities v Ireland 18.11.2010 (ECJ). 
(c) of Directive $89 / 665$ provides that Member States must ensure that damages are awarded to persons harmed by an infringement of the EU law on public procurement. Moreover Article 2(7) of Directive 89/665, as amended by Directive $2007 / 66$, provides that, except where a decision must be set aside prior to the award of damages, the right of the person harmed by an infringement might be limited to compensation of dámages.

In the case Stadt Graz, ${ }^{40}$ the ECJ held that EU law precludes 'national legislation which makes the right to damages for" an infringement of public procurement law by a contracting authority conditional on that infringement being culpable, including where the application of that legislation rests on a presumption that the contracting authority is at fault and on the fact that the latter cannot rely on a lack of individual abilities, hence on the defence that it cannot be held accountable for the alleged infringement'.

In two prior judgments, ${ }^{41}$ the ECJ had held that EU law precludes a national law that makes the right to damages conditional on the fact that the injured party should prove fault on the part of the contracting authority. With its decision in the case Stadt Graz, the ECJ made clear that any liability of the contracting authority for infringements against EU public procurement law is strict, ie completely independent of fault, either proven or presumed. The ECJ considered that under some circumstances (ie when the injured party may not claim the annulment of the infringing decision, either because of the limitation period, or because the Member State implementing Directive 89/665 opted for a system where after the conclusion of the contract annulment is not available) the action for damages is the only remedy available to the person who suffered the infringement. Therefore, an action for damages should not be subject to greater limitations than the action for annulment, such as a requirement of fault. ${ }^{42}$ Moreover, the requirement of fault, even if presumed, may imply a delay in the review procedure, therefore undermining the requirement of Article 1(1) of Directive 89/665 that procedures should be reviewed 'as rapidly as possible'. ${ }^{43}$

Until its amendment by Directive 66/2007, Directive 89/665 did not foresee any specific rule on a limitation period (prescription) of the right to damages. With the case Uniplex, ${ }^{44}$ the ECJ had the opportunity to clarify the law also in this respect. The Court held that the principle of effectiveness requires that the limitation period does not start to run until the claimant knows or ought to

40 Case 314/09 Stadt Graz v Strabag 30.9.2010 (ECJ).

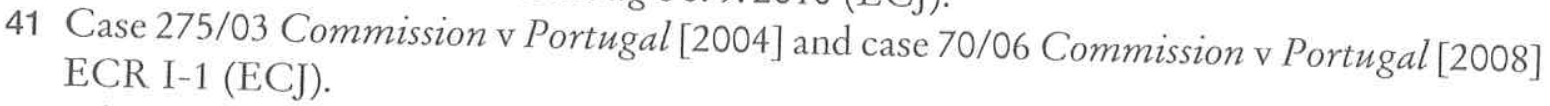

42 Cf case 314/09, n 40 above, par 37-41.

43 Ibid par 42.

44 Case 406/08 Uniplex v NHS Business Services Authority 28.1.2010 (ECJ). 
have known about the fact of the infringement. More precisely, in order for the claimant to be able to assess the existence of the infringement, the limitation period should not start to run before he knows or ought to have known the reasons of the decision of the contracting althority that caused the harm for which he seeks compensation. As far as the length of the limitation period is concerned, the ECJ held that the principle of effectiveness requires that it be set in a clear manner. Therefore, a national rule stating that the claimant must act 'promptly' (as in the case decided by the ECJ) does, not satisfy this requirement.

\section{Influence of EU law on national review procedures}

In some national laws the members of a consortium of economic operators that participated in a procedure for the award of a public contract are required to claim jointly for the annulment of the decision of the contracting authority that infringed against EU law on public procurement. The rationale behind this rule is that the interest in obtaining the public contract rests with the consortium as a whole and not with its single members individually. In its decision in the case Espace Trianon and Sofibail, ${ }^{45}$ the ECJ held that such a national rule is not against EU law. However, as the ECJ clarified in its subsequent decision in the case Consorzio Elisoccorso San Raffaele,${ }^{46}$ the opposite rule (ie the possibility for each member of the consortium to act individually for the annulment of the infringing decision) is also not against EU law. Therefore, Member States are free to decide whether to allow or not single members of a consortium to act individually for the annulment of the infringing decision.

A related issue arises when the national law that denies the single member of the consortium the standing for the annulment of the infringing decision also prescribes that a claim for damages may only be brought when the annulment of the infringing decision is sought as well. In such a system, the single member of the consortium is deprived not only of the right to act individually for the annulment of the decision, but also of the right to act individually to obtain the compensation of damages. In the recent joined cases Club Hotel Loutraki and Aktor ATE, ${ }^{47}$ the ECJ held that such a system that deprives the single member of the consortium of any kind of individual relief against an infringing decision is contrary to EU law. The case at hand was complicated by the fact that the infringing decision was taken by a public authority that was independent from the contracting authority. The ECJ held that Directive 89/665 did not apply. However, the ECJ held that the principle of effective judicial protection -

45 Case 129/04 Espace Trianon and Sofibail [2005] ECR I-7805 (ECJ).

46 Case 492/06 Consorzio Elisoccorso San Raffaele [2007] ECR I-8189 (ECJ).

47 Joined cases 145/08 and 149/08, n 30 above. 
requiring that the single member of the consortium had the right to seek compensation of damages - is a general principle of EU law, which applied to the case at hand irrespective of the fact that it was within or without the reach of Directive 89/665.

\section{EU law and performance of public contracts}

As was already mentioned in the introduction," EU law on public contracts is mostly concerned with open competition between European economic operators. Therefore, EU law is mostly, if not exclusively, focused on the precontractual phase of the award procedures. However, recent decisions of the ECJ have extended the reach of EU law also to the subsequent phase of the performance or execution of the contract.

In its decisions in the cases Cómmission v France and pressetext Nachrichtenagentur, the ECJ held that amendments to the provisions of a public contract during its performance require a new contract award procedure, if they are materially different in character from the original contract. ${ }^{48}$ Amendments should be considered as material if they considerably extend the scope of the contract, or if they change the economic balance of the contract, or more generally when they introduce new conditions which would have permitted the participation or the success of other tenderers. ${ }^{49}$

More recently, in the case Wall $A G{ }^{50}$ the ECJ held that a material amendment might in exceptional cases also consist in a change of the subcontractor, even if the possibility of such a change was provided for in the contract. Moreover, in the same case, the ECJ extended its previous case law dealing with material amendments in public contracts also to the field of service concessions.

It is clear that the extension of the reach of EU law to contract performance still responds to concerns about free competition within the internal market. Therefore, in the case Wall AG, the ECJ held that depending on the circumstances 'a new award procedure would have to be organized in a manner appropriate to the specific features of the service concessions involved, and would have to ensure that an undertaking located in another Member State had access to sufficient information on that concession before it was awarded'. ${ }^{51}$ A potentially much greater scope characterizes the proposal of the Commission in the Green paper on the modernisation of EU public procurement policy to extend even farther the reach of EU law on performance of the public

48 Case 337/98 Commission v France [2000] ECR I-8377 (ECJ), par 44, 46, and case 454/06 pressetext Nachrichtenagentur [2008] ECR I-4401 (ECJ) par 34-37.

49 Case 454/06, n 48 above, par 35-37.

50 Case 91/08 Wall AG v FES 13.4.2010 (ECJ).

51 Ibid par 42. 
contract. The Commission argues that 'national regulation on the implementation of contracts is quite detailed in many Member States and can be a source of administrative burden (eg rules on execution guarantees, delivery conditions, delays, pricing of adjustments, etc). Thé number of national rules in this field could possibly be reduced by introducing common standards for certain aspects at EU level'. ${ }^{52}$

The great majority of interested parties took the position that performance of the public contract should be left to national law. ${ }^{53}$ However, there are some good reasons to favour some kind of harmonization of European national laws also with respect to the stage of performance of public contracts. For example, it seems clear that the diversity of national laws on performance of public contracts represents a major obstacle to a greater participation in award procedures of economic operators from different Member States. Moreover, it may not be ruled out that certain Member States make a strategic use of contractual provisions on performance of the public contract, in order to disfavour the participation of economic operators from other Member States.

52 Green Paper, n 2 above, 26.

53 Green Paper on the modernisation of EU public procurement policy - Synthesis of replies, 13 at http://ec.europa.eu/internal_market/publicprocurement/modernising rules/consultations/index_en.htm (last visited 15 August 2011). 


\begin{abstract}
ARTICLES
Gregor Christandl

The 'dying' offer Rule in European Contract Law . 463

Stefan Grundmann

The Future of Contract Law

490

\section{CASE NOTE}

Hans-W. Micklitz

German Constitutional Court (Bundesverfassungsgericht BVerfG) 2 BvE 2/O8, 30. 6. 2009 - Organstreit proceedings between members of the German Parliament and the Federal Govehnment

528
\end{abstract}

\title{
EU LEGISLATION
}

Rossella Delfino

European Union legislation and Actions

547

\section{SECTORAL AND NATIONAL DEVELOPMENTS}

Andrea Mozzati and Giorgio Afferni

RECENT DEVELOPMENTS IN THE EUROPEAN LAW OF PUBLIC CONTRACTS

552

\section{BOOKS RECEIVED AND BOOK REVIEWS}

Carole Aubert de Vincelles

H. Schulte- Nölke and L. Tichy (eds), Perspectives for European Consumer Law. Towards a Directive on Consumer Rights and Beyond 567

Michele Graziadei

Gert Brüggemeier, Aurelia Colombi Ciacchi, Giovanni Comandé (eds), Fundamental Rights and Private Law in the European Union: Volume I: A Comparative Overview; Volume II: Comparative Analyses of Selected Case Patterns

573 


\section{EUROPEAN REVIEW OF CONTRACT LAW (ERCL)}

\section{MANAGING BOARD}

Prof. Hugh Collins, London

Prof. Muriel Fabre-Magnan, Paris

Prof. Dr. Dr: Stefan Grundmann, LL.M. (Managing Editor)

Prof. Dr. Martijn W. Hesselink, Amsterdam

Prof. Vincenzo Roppo, Genova

\section{CONSULTING BOARD}

Prof. Avv. Guido Alpa, Genova/Roma

Prof. Hugh Gurney Beale, Warwick/London

Prof. Avv. Cesare M. Bianca, Roma

Prof. Jacques Caillosse, Paris

Prof. Bénédicte Fauvarque-Cosson, Paris

Prof. Dr. Daniel Friedmann, LL.M, Tel Aviv

Prof. Gerrit De Geest, Utrecht

Prof. Dr. Fernando Gómez, Barcelona

Prof. James R. Gordley, Berkeley

Prof. Dr. Aristides Hatzis, LL.M., Athens

Prof. Dr. Johnny Herre, Stockholm

Prof. Dr. Dr. Dres. h. c. Klaus J. Hopt, Hamburg

Prof. Christophe Jamin, Paris

Prof. Dr. Dr. h. c. mult. Konstantinos Kerameus,

Athens

Prof. Dr: Ole Lando, Frederiksberg/Copenhagen

Prof. Dr. Brigitta Lurger, LL.M. (Harvard), Graz

Prof. Ugo Mattei, Torino
Prof. Dr. Depis Mazeaud, Paris

Prof. António Pinto Monteiro, Coimbra

Prof. Horatia Muir Watt, Paris

Prof. Dr. Jerzy Rajski, Warsaw

Prof. Dr: Robert Rebhahn, Wien

Prof. Dr. Karl Riesenhuber, M.C.J., Bochum

Prof. Dr. Martin Schauer, Wien

Prof. Dr. Pietro Sirena, Siena

Prof. Jules Stuyck, Leuven

Prof. Dr. Walter van Gerven, Leuven

Prof. Paul Varul, Tartu

Prof. Dr. Lajos Vékás, Budapest

Prof. Stephen R. Weatherill, Oxford

Prof. Dr. Harm Peter Westermann, Tübingen

Prof. Dr. Dr. Thomas Wilhelmsson, Helsinki

Prof. Dr. Dr. h. c. mult. Reinhard Zimmermann,

Hamburg

All rights reserved, including those of translation into foreign languages. No part of this journal may be reproduced or transmitted in any form or by any means, electronic or mechanical, including photocopy, recording, or any information storage or retrieval system, without permission in writing from the publisher.

ISSN 1614-9920 · e-ISSN 1614-9939

All information regarding notes for contributors, subscriptions, open access, back volumes and orders is available online at www.degruyter.com/ercl.

RESPONSIBLE EDITOR Prof. Dr. Dr. Stefan Grundmann, LL.M., Humboldt-Universität zu Berlin, Juristische Fakultät, Lehrstuhl für Bürgerliches Recht, Deutsches, Europäisches und Internationales Privat- und Wirtschaftsrecht, D-10099 Berlin, Fax: +49 (0)30 2093-3497, Email: Stefan.Grundmann@rewi.hu-berlin.de; Assistant to the Managing Editor: Sonja Firl, same address,

Email:ercl@rewi.hu-berlin.de

JOURNAL MANAGER Christiane Geißler, De Gruyter, Genthiner Straße 13, 10785 Berlin, Germany, Tel.: +49 (0)30 26005 - 260, Fax: +49 (0)30 26005 - 250, Email: christiane.geissler@ degruyter.com

RESPONSIBLE FOR ADVERTISEMENTS Panagiota Herbrand, De Gruyter,

Mies-van-der-Rohe-Straße 1, 80807 München, Germany, Tel.: +49 (0)89 76902 - 394,

Fax: +49 (0)8976902 - 350, Email: panagiota.herbrand@ degruyter.com

(C) 2011 Walter de Gruyter GmbH \& Co. KG, Berlin/Boston

TYPESETTING jürgen ullrich typosatz, Nördlingen

PRINTING AZ Druck und Datentechnik GmbH, Kempten

Printed in Germany 